11th.-Morning: Temperature $101.5^{\circ}$; pulse 116; respiration 45 .

12th.-Morning: Temperature $101^{\circ}$; pulse 108 ; respiration 40.

13th.-Morning : Temperature $99.6^{\circ}$; pulse 104 ; respiration 36.

22nd.-All pain and swelling have subsided.

In publishing this case it is not my intention to advocate the universal adoption of acids in the treatment of acute rheumatism, but rather to show that such treatment need not be considered either dangerous or injurious. I believe, nerertheless, that, were acids widely tried, they would be found less to retard recovery than large doses of alkalies. The treatment may be considered tonic, and classed with quinine and iron, both of which are extensively employed in this affection.

I ought to add, that the publication of these remarks was suggested to me by seeing the case reported from Dr. Wilks's clinique in THe LANCET of the 14ith inst. St. Thomas's-street, S.E.

\section{CALCAREOUS DEGENERATION OF THE LEFT TESTICLE.}

BY WM. GUEST CARPENTER, F.R.C.S.

I WAS sent for to see Mr. S-, seventy years of age, who was confined to his bed from extreme weakness, brought on by a long-continued discharge of very offensive matter from the scrotum. Mr. S- was by occupation a farmer, bachelor, of very quiet habits, disliking society. His niece was his housekeeper. She told me her uncle had been failing in bealth for some time, and would not have any medical advice; but, finding weakness increased upon him, and the smell from some wound he had was so offensive she could hardly sit in the room with him, she prevailed upon him to send for me. I detected the smell as soon as I entered the bedroom. He was in bed, his voice was very feeble, pulse weak and intermitting, hands and feet cold, nails livid, tongue dry and rather brown. On examining the scrotum I found it very much enlarged on the left side by an elongated hard swelling, about five inches long. T'here was a sinus on the front part, through which a very offensive sanious fluid oozed. The tumour was as hard as a stone. On passing the probe into the opening it grated against a hard, irregular substance. I enlarged the opening with a bistoury, syringed warm water into the scrotum, and succeeded in extracting a flat piece of hard calcareous substance, $\frac{1}{12}$ inch in thickness, resembling bone. satisfied myself what the nature of the case was. I prescribed a tonic of bark and ammonia; ordered four glasses of port wine daily, and brandy-and-water at his meals, with beef-tea in the intervals.

I visited him every day, injecting warm water each time, and extracting pieces of the calcareous matter. In about a week his health began to improve. At the end of a month I had cleared out all the calcareous matter. I found the testicle gone-destroyed. When the wound healed there was a little thickening of the scrotum. It returned to nearly its natural size.

Mr. S _ was very much weakened by this disease, and his friends expected daily to hear of his death. At the end of six weeks I took my leave of him, and he afterwards enjoyed good health, and lived beyond the age of eighty. Clifton-terrace, Maida-vale.

Royal Humane Society.--In the month of April next, 100 years will have elapsed since the foundation of the Royal Humane Society, and the committee have decided on holding a centenary festival, at which H.R.H. the Duke of Edinburgh has expressed bis intention of presiding, to celebrate the great success which has resulted from its exertions to preserve life, and to improve and circulate all over the world the simplest and most scientific modes of treatment in cases of suspended animation. Due notice will be given of the day fixed for the festival, as soon as possible after the return of His Royal Highness from Russia.

\section{g a dittitut}

\author{
HOSPITAL PRACTICE, \\ BRITISH AND FOREIGN.
}

Nulla autem est alia pro certo noscendi via, nisi quamplurimas et morborum et discectionum historias, tum aliorum, tum proprias collectas habere, et inter se comparare.-Morgagri De Sed. et Caus. MKorb., lib. iv. Procminm.

\section{ST. THOMAS'S HOSPITAL.}

CASES OF TUBERCULAR MENINGITIS.

THE following is a continuation of the series of cases of tubercular meningitis which was commenced last week.

The second case is one of more interest from the coexistence of old caseous masses in the cerebellum, which had probably produced the difficulty in walking. Unfortunately the history is incomplete as to the nature of the difficulty.

Henry W-, aged eleven, was admitted under the care of Dr. Bristowe on the 6th of June, 1873. The father is living and healthy; mother said to be consumptive; of thirteen children ten are living and healthy, three died in infancy. Patient was always delicate; is said to have had rheumatic fever three or four years ago. Two years ago he had two fits in which he remained motionless for about twenty minutes. He was always "weak in the legs"; and twelve months ago entirely ceased to walk. Occasionally suffered from pain in the head, but not usually severe. For the last fortnight he has suffered from severe headache, the pain being chiefly frontal, and in the eyes. Has not had diarrbœa or vomiting; the bowels were open two days before admission. Had wandered a little the last three nights.

On admission, June 6 th, 3 P.M., the patient was thin and weakly-looking, head large, forehead prominent. He was quite sensible and intelligent, complained of severe frontal headache and pain in the eyes and dimness of sight. No paralysis of facial or ocular muscles. Right pupil was slightly larger than left, and did not act so well to light; both pupils dilated readily; although there was no strabismus, he could not easily keep his eyes turned to either side. No diplopia. The face alternately flushed and grew pale very readily, without evident cause. Temperature $102^{\circ}{ }^{\circ}$; pulse 124, regular; appetite bad; tongue slightly coated with white fur. Abdomen somewhat retracted, and extremely sensitive when touched, the slightest touch causing sudden retraction of the muscles and great pain; no tenderness on percussion, but the patient complained of some pain on pressure in the right iliac and splenic regions. Tâche cérébrale readily produced over abdomen and chest; over the latter there is much less hyperæsthesia. Nothing abnormal detected in lungs; heart sounds healthy. Whilst lying in bed he could draw up both legs with ease and without pain, and there was no evident paralysis either motor or sensory, but he could not stand. When moved he complained of great pain in the nape of the neck. Has perfect control over rectum and bladder. -8.30 P.M. : Temperature $1019^{\circ}$.

June 7th.-Temperature: 9 A.M., $100 \cdot 3^{\circ}$; 12 noon, $100 \cdot 6^{\circ}$; 4 P.M., $100^{\circ} 4^{\circ}$. Pulse 96 to 100 , fairly regular and equal. Rambled a little last night. To-day is much the same. He can read very large type with either eye, but with the right eye is unable to read "English" type, which he can with the left. Ophthalmoscopic examination: In the right eye, outline of disc indistinguishable, and the whole disc obscured by effusion; veins distended and tortuous; arterial branches numerous, but do not appear large; some portions of the vessels, especially towards the middle of the disc, are hidden by patches of exudation. In the left eye, dise visible, outer margin distinct, inner blurred; slight exudation along vessels, which are distended; neuritis much less marked than in the right eye.

8th.-Temperature-morning, $99^{\circ}$; evening, $1009^{\circ}$.

9th.-Much the same as before. Temperature at 10.30 A.M., $1003^{\circ}$; pulse 96 , regular ; bowels confined ; no vomiting. Headache continues, and there is slight internal strabismus of the left eye. No delirium.

10th.-Has been delirious at times since yesterday aftor- 